Syntax Literate : Jurnal Ilmiah Indonesia p-ISSN: 2541-0849

e-ISSN : 2548-1398

Vol. 5, No. 3 Maret 2020

\title{
COLLABORATIVE GOVERNANCE DALAM PELAYANAN TRANSPORTASI PUBLIK (STUDY BRT TRANS SEMARANG)
}

\section{Agung Nurul Falaq Adi Wibowo}

Program Studi Magister Administrasi Publik Universitas Diponegoro Semarang

Email: agungnurulfalaq@yahoo.co.id

\begin{abstract}
One of the strategies of Semarang city government to overcome congestion is by establishing a mass transit system that cooperates with various parties. Collaboration carried out some problems that resulted in the decline in Trans Semarang services so that complaints arising from service users. For this, it is necessary to analyze the collaboration process and to find a collaborative blocking factor in the Trans Semarang service. The purpose of this research is to analyze the cooperation process conducted by UPTD Trans Semarang with the operators of BRT Trans Semarang Public transport service in Semarang and to identify various factors that impede collaborative governance in BRT Trans Semarang Public transportation services in Semarang. The results showed that in the phase of Trust development of the internal conflict BLU UPTD Trans Semarang, where some parties refused to carry out the leadership policy. In the phase of Share Understanding, there is a difference between operator desires and policies set by the BLU UPTD Trans Semarang. While the factors that inhibit collaboration in public transport services are cultural factors and institutional factors. Therefore, the level of Trust Building for training, re-test, and re-selection of employees is recommended. While the Share Understanding stage is performed coordination of meetings to unite the wishes of operators and governments.
\end{abstract}

Keywords: Collaborative Governance, public administration, public transportation

\begin{abstract}
Abstrak
Salah satu strategi Pemerintah Kota Semarang untuk mengatasi kemacetan adalah dengan membangun sistem Transportasi massal berkolaborasi dengan berbagai pihak. Kolaborasi yang dilaksanakan terdapat beberapa permasalahan yang berakibat pelayanan Trans Semarang menurun sehingga muncul keluhan-keluhan pengguna jasa. Untuk itulah perlu dilakukan analisis terhadap proses kolaborasi dan untuk mencari faktor-faktor penghambat kolaborasi dalam pelayanan Trans Semarang. Tujuan penelitian ini adalah untuk menganalisis proses kolaborasi yang dilakukan UPTD Trans Semarang dengan operator-operator dalam pelayanan transportasi publik BRT Trans Semarang di Kota Semarang dan untuk mengidentifikasi faktor-faktor yang menghambat collaborative governance dalam pelayanan transportasi publik BRT Trans Semarang di Kota Semarang. Hasil penelitian menunjukkan bahwa dalam tahap Trust building terjadi konflik internal BLU UPTD Trans Semarang,dimana sebagian pihak menolak melaksanakan kebijakan pimpinan. Sedangkan pada tahap Share Understanding terjadi ketidaksesuaian antara keinginan operator dengan kebijakan yang
\end{abstract}


ditetapkan oleh BLU UPTD Trans Semarang. Sedangkan faktor-faktor yang menghambat kolaborasi dalam pelayanan transportasi publik ini adalah faktor budaya dan faktor institusi. Untuk itu disarankan, pada tahap Trust building untuk melakukan pelatihan-pelatihan, test ulang dan seleksi ulang pada karyawan. Sedangkan pada tahap Share Understanding dilakukan rapat koordinasi untuk menyatukan keinginan operator dan Pemerintah.

Kata kunci :Collaborative Governance, Administrasi Publik, Transportasi Publik

\section{Pendahuluan}

Sebagai salah satu kota yang mengalami kemajuan yang pesat Semarang pasti memiliki beberapa masalah perkotaan, salah satu diantaranya adalah masalah kemacetan lalu lintas di jalan raya dan banyaknya aksi demonstrasi, blokir jalan dan tuntutan agar transportasi online dibubarkan (Suhaeri, 2018). Kemacetan ini timbul karena semakin tingginya volume kendaraan pribadi yang tidak seimbang dengan pembangunan infrastruktur yang cepat, dan kurang disiplinnya para pengendara dalam menggunakan kendaraannya. Di Kota Semarang jumlah kendaraan roda 2 meningkat 13-14 persen per tahun dan roda 4 meningkat 8-10 persen per tahun. Jumlah kendaraan roda dua maupun roda empat mencapai 2,4 juta (1,1 juta motor dan 1,3 juta mobil) lebih tinggi dari jumlah penduduk Kota Semarang sebanyak 1,7 juta jiwa. Jika tidak ada upaya pembenahan Pola Transportasi, pada tahun 2017 Semarang akan mengalami kemacetan total (Pusat Data dan Informasi Kementerian Perhubungan, 2016).

Melihat kondisi sekarang ini, Kota Semarang semakin hari semakin macet, penataan sistem transportasi harus dilakukan secara terpadu sebagai satu kesatuan sistem transportasi nasional agar mampu mewujudkan tersedianya jasa transportasi yang seimbang dengan tingkat kebutuhan permintaan pelanggan, yang layak dengan biaya murah sehingga dapat terjangkau oleh seluruh rakyat. Salah satu aspek transportasi yang menyangkut hajat hidup orang banyak adalah angkutan umum. Pengembangan angkutan umum massal berbasis jalan di wilayah perkotaan di Indonesia diarahkan untuk menciptakan pelayanan yang handal dan pada jangka panjang, diharapkan keberadaan pelayanan angkutan umum yang handal akan mampu mengurangi ketergantungan masyarakat terhadap penggunaan kendaraan pribadi.

Transportasi darat merupakan sarana angkutan penumpang umum yang memegang peranan penting dalam menunjang aktifitas dan mobilitas mayarakat. Tanpa sarana angkutan umum, masyarakat akan menggunakan angkutan pribadi yang akan membuat kemacetan lalu lintas akan sangat parah. Melihat pentingnya angkutan umum dalam menunjang aktifitas dan mobilitas masyarakat serta amanat dari Undang-Undang Nomor 22 Tahun 2009 Tentang Lalu Lintas dan Angkutan Jalan inilah maka pada tahun 2010 Kementerian Perhubungan Republik Indonesia membuat program revitalisasi angkutan umum perkotaan.

Program Revitalisasi Angkutan Umum yang dilaksanakan oleh Kementerian Perhubungan ini adalah menstimulasi Pemerintah Daerah untuk melaksakan perbaikan 
pelayanan angkutan umum. Stimulasi yang dilaksanakan Kementerian Perhubungan adalah dengan memberikan bantuan armada Bus Rapid Transit, dengan adanya bantuan armada ini maka diharapkan Pemerintah Daerah akan memperbaiki pelayanan angkutan umum. Dalam Pasal 38 Undang-Undang Nomor 22 Tahun 2009 dinyatakan bahwa Pemerintah bertanggung jawab atas penyelenggaraan angkutan umum yang selamat, aman, nyaman dan terjangkau.

Berdasarkan amanat Undang-Undang tersebut serta stimulasi dari Kementerian Perhubungan maka mulai 9 Oktober 2009 Pemerintah Kota Semarang mulai mengembangkan Transportasi Publik yaitu Bus Rapid Transit (BRT) Trans Semarang. BRT Trans Semarang adalah sebuah sistem transportasi bus cepat, murah dan ber-AC yang dioperasikan oleh Dinas Perhubungan, Komunikasi dan Informatika Kota Semarang. BRT Trans Semarang pada awalnya ditujukan untuk membenahi system layanan angkutan umum di Kota Semarang yang telah ada selama ini dan kemudian dikembangkan menjadi satu sistem transportasi publik yang memiliki keunggulan berupa kenyamanan, keteraturan, keamanan, dan harga ekonomis.

Pemerintah Kota Semarang sebagai wakil Pemerintah Pusat yang berada di Daerah wajib memberikan pelayanan publik (public service) yang berkualitas. Bentuk birokrasi pemerintah yang hierarki yang selama ini menjadi model dalam menjalankan layanan publik perlu diubah dengan pendekatan baru, yaitu sistem pemerintahan responsif dengan melibatkan pemerintah, masyarakat sipil dan sektor swasta. Dalam literatur administrasi publik keterlibatan pemerintah, swasta dan masyarakat disebut governmence. Konsep governmence menekankan gagasan bahwa tidak ada organisasi tunggal dalam penyelenggaraan pemerintahan dan pelayanan publik. Untuk memenuhi kebutuhan publik, tujuan dan sasaran bersama dapat dicapai secara efektif melalui proses kolaborasi. Aktor-aktor yang terlibat dalam proses kolaborasi harus mengembangkan struktur kerja dalam rangka menjamin penyelenggaraan layanan publik yang efektif, akuntabel, transparan dan responsif.

Untuk mengatasi semakin meningkatnya kemacetan dan mengatasi buruknya sistem transportasi yang ada di Kota Semarang, maka pemerintah membangun sistem BRT (Bus Rapid Transit) Trans Semarang di Kota Semarang. Saat ini BRT Trans Semarang telah membuka 7 Koridor, yaitu Koridor 1 jurusan Mangkang-Penggaron, Koridor 2 jurusan Terboyo-Sisemut Ungaran, Koridor 3 jurusan Pelabuhan Tanjung Emas-Akpol, Koridor 4 Terminal Cangkiran - Bandara Ahmad Yani-Stasiun Tawang, Koridor 5 Meteseh-PRPP, Koridor 6 UNDIP Tembalang-UNNES Sekaran dan Koridor 7 Terboyo-Pemuda.

BRT Trans Semarang mengoptimalisasi pengangkutan dalam jumlah massal dengan penggunaan bus berukuran besar dan sedang yang dinilai sesuai dengan keadaan jalanan Semarang. BRT Trans Semarang menjadi salah satu daya tarik bagi wisatawan dan memudahkan warga Semarang mengelilingi Kota Semarang. Hal tersebut dapat dilihat melalui tabel 1 jumlah pengguna/penumpang BRT di Kota Semarang yang mengalami peningkatan sebagai berikut : 
Tabel 1

Jumlah Penumpang BRT Trans Semarang Tahun 2011-2018

\begin{tabular}{clccc}
\hline \multirow{2}{*}{ Tahun } & \multicolumn{2}{c}{ Jumlah } & \multicolumn{2}{c}{ Realisasi Penumpang } \\
\cline { 2 - 5 } & \multicolumn{1}{c}{ Koridor } & Umum & Pelajar & $\begin{array}{c}\text { Total } \\
\text { Penumpang }\end{array}$ \\
\hline 2011 & 1 ( KOR I) & 1.195 .436 & 483.106 & 1.678 .542 \\
\hline 2012 & 2 ( KOR I \& II) & 1.476 .979 & 533.722 & 2.010 .701 \\
\hline 2013 & 3 (KOR I, II, \& IV) & 3.116 .157 & 702.421 & 3.818 .578 \\
\hline 2014 & 4 (KOR I, II, III \& IV) & 4.232 .891 & 1.588 .984 & 5.821 .875 \\
\hline 2015 & 4 (KOR I, II, III \& IV) & 5.931 .699 & 2.092 .170 & 8.023 .869 \\
\hline 2016 & 4 (KOR I, II, III \& IV) & 5.851 .425 & 1.874 .065 & 7.725 .490 \\
\hline 2017 & 6 (KOR I, II, III, IV, V dan VI) & 6.541 .592 & 2.583 .880 & 9.125 .472 \\
\hline 2018 & 7 (KOR I, II, III, IV, V dan VII) & 7.066 .264 & 3.144 .032 & 10.210 .296 \\
\hline \multicolumn{2}{c}{ Sumber : DISHUB Kota Semarang } & & & \\
\hline
\end{tabular}

Pelaksanaan operasional Trans Semarang ini dilaksanakan oleh UPTD Trans Semarang yang bekerja sama dengan Operator dalam menjalankan Bus Trans Semarang. Pemilihan operator dilakukan melalui lelang Operasional Trans Semarang melalui lelang di Unit Layanan Pengadaan (ULP) Kota Semarang. Pelayanan publik dalam bidang transportasi Trans Semarang ini merupakan pelayanan publik yang diselenggarakan oleh Pemerintah bekerja sama dengan pihak ketiga selaku operator dan masyarakat selaku pengguna layanan.

Alasan utama diperlukan kolaborasi antara Pemerintah dan Pihak Swasta adalah agar berbagai masalah terkait penyelenggaraan transportasi umum dapat terharmonisasi dengan baik. Peran pemerintah sebagai regulator kebijakan, perlu melakukan kerjasama dengan pihak swasta, sehingga dapat mengatasi masalah keterbatasan dana, efisiensi dan efektivitas pemerintahan, dan pertanggungjawaban pemerintah kepada masyarakat. Oleh karena itu Pemerintah perlu menarik pihak swasta untuk melakukan investasi tidak hanya dalam bentuk dana tetapi juga peningkatan skill sumber daya manusia untuk membangun dan memelihara infrastruktur yang belum dan sudah tersedia dalam rangka mensejahterakan masyarakat.

Pelaksanaan operasional BRT Trans Semarang merupakan tanggung jawab dari Pemerintah Kota Semarang yang dalam hal ini dilaksanakan oleh Badan Layanan Umum Unit Pelaksana Teknis Daerah (BLU UPTD) Trans Semarang. Dalam pelaksanaan operasional BRT Trans Semarang tersebut UPTD Trans Semarang memiliki beberapa kendala yang tidak dapat mengelola dengan swakelola sehingga harus bekerja sama dengan pihak lain. Proses kerja sama dengan pihak lain dilakukan dengan pemilihan pihak lain melalui proses lelang. Setelah dilakukan proses lelang tersebut didapat pemenang lelang yang akan bekerja sama dengan UPTD Trans Semarang. Dalam kerja sama atau kolaborasi ini terdapat pembagian tugas dalam melaksanakan operasional BRT Trans Semarang. 
Perspektif collaborative governance juga telah banyak digunakan untuk pemecahan masalah daerah lokal karena adanya keterbatasan pemerintah lokal dalam menjalankan pemerintahan di daerahnya. Karena perspektif collaborative governance merupakan proses yang melibatkan banyak aktor kebijakan untuk dapat dikatakan sebagai tata kelola pemerintahan yang baik atau good governance.

Berdasarkan uraian tersebut, maka penulis memiliki ketertarikan untuk melakukan penelitian dengan judul "Collaborative Governance dalam Pelayanan Transportasi Publik (Studi BRT Trans Semarang)".

\section{Metode Penelitian}

Pendekatan yang digunakan dalam penelitian ini adalah penelitian kualitatif yang mana penelitian kualitatif dapat diartikan sebagai penelitian yang menggunakan data yang objektif dan tepat dengan permasalahan yang ada. Metode penelitian kolaborasi yang dijalin antara pemerintah dengan pihak ketiga dalam penyediaan transportasi publik BRT (Bus Rapid Transit) Trans Semarang, yang sesuai dengan rumusan masalah, tujuan, dan manfaat penelitian, akan lebih lengkap, lebih mendalam, kredibel, dan memiliki kredibiltas sehingga tujuan penelitian dapat tercapai. Data yang diperoleh disusun secara sistematis kemudian dianalisis secara kualitatif untuk mencapai kejelasan masalah yang dibahas.

Tipe penelitian yang digunakan yaitu tipe penelitian deskriptif dengan metode kualitatif, dimaksudkan untuk memberikan gambaran secara jelas mengenai masalah yang diteliti, mengidentifikasi dan menjelaskan data yang ada secara sistematis. Tipe deskriptif bertujuan untuk mendeskripsikan, mencatat, analisis dan menginterprestasikan kondisi-kondisi yang sekarang ini terjadi (Mardalis, n.d.). Dengan melakukan pengambilan data secara langsung di lapangan baik dengan metode wawancara langsung, kemudian hasil data tersebut akan di analisis dan di deskripsikan kemudian disimpulkan apakah pelayanan yang dilakukan oleh pengelola BRT Trans Semarang dalam hal ini Pemerintah dan pihak ketiga tersebut sudah efektif ataukah belum.

Pengumpulan data dalam penelitian ini adalah untuk memperoleh informasi yang mengarah pada penemuan jawaban terhadap permasalahan yang sedang diteliti serta melengkapi data-data pendukung yang menunjukkan kemaksimalan dalam penelitian. Dalam memperoleh data-data ada empat Teknik pengumpulan data yang penulis gunakan yaitu:

1) Observasi (pengamatan)

Sutrisno Hadi dalam (Sugiyono, 2016) mengemukakan:

"Observasi merupakan suatu proses yang kompleks, suatu proses yang tersusun dari berbagai proses biologis dan psikologis. Dua diantara nya yang terpenting adalah proses pengamatan dan ingatan."

Dalam penelitian ini, observasi dilakukan dengan cara pengamatan langsung pada lapangan. 
2) Wawancara

Sumber data utama melalui wawancara terstruktur (Moleong, 2005) adalah wawancara yang pewawancaranya menetapkan sendiri masalah dan pertanyaan-pertanyaan yang diajukan. Wawancara yang digunakan adalah wawancara terstruktur yaitu peneliti sudah memiliki panduan wawancara tentang hal-hal yang akan ditanyakan sesuai dengan tujuan dan kebutuhan.

3) Dokumentasi

Dokumentasi yaitu cara pengumpulan data dan telaah pustaka dimana dokumen-dokumen yang dianggap menunjang dan relevan dengan permasalahan yang akan diteliti.

\section{Hasil dan Pembahasan}

\section{A. Hasil Penelitian}

\section{Penyajian Data}

Kolaborasi dilakukan antara Pemerintah Daerah Kota Semarang dengan Operator bus dan Pemerintah Kota Toyama Jepang dalam pelayanan transportasi publik. Kolaborasi penting dilakukan untuk saling membantu antara instansi pemerintah dengan institusi lainnya dengan peran mereka masing-masing untuk mengatasi permasalahan yang dihadapi pemerintah dalam pelayanan transportasi publik seperti :

1) Keterbatasan sarana transportasi seperti Armada Bus,

2) Keterbatasan sumber daya manusia untuk operasional bus seperti pengemudi dan petugas lapangan,

3) Keterbatasan kemampuan dalam operasional dan perawatan kendaraan,

4) Polusi udara yang dihasilkan oleh emisi gas buang

Oleh karena itu, pemerintah memberikan repon dengan menjalin kerjasama dengan stakeholders untuk menghadapi permasalahan atau keterbatasan yang dihadapi oleh pemerintah dengan melakukan upaya sebagai berikut :

1) Lelang operasional bus

Operasinal Bus Trans Semarang pada tahun 2008 adalah dengan menggunakan bus bantuan pemerintah pusat sejumlah 20 kendaraan. Seiiring dengan perkembangan kota Semarang maka koridor bus trans Semarang bertambah yang berakibat pada kebutuhan jumlah armada juga bertambah. Pemerintah pusat melalui Kementerian Perhubungan telah memberi bantuan armada bus kepada pemerintah kota Semarang namun bantuan bus tersebut tidak bisa mencukupi kebutuhan untuk penambahan sejumlah 7 koridor sehingga pemerintah Kota Semarang melakukan kerjasama dengan pihak konsorsium pengusaha angkutan untuk pengadaan dan mengoperasionalkan bus milik swasta.

2) Menjalin kerjasama dengan sesama instansi yang terkait dengan pelayanan Trans Semarang untuk membangun sarana dan prasarana. 


\section{Analisis data}

Analisis data mengenai Collaborative Governance dalam Pelayanan Transportasi Publik (Studi BRT Trans Semarang) yaitu meliputi Face to face, trust building, comitment to prosses, share understanding dan intermediate outcomes.

Pada kolaborasi pelayanan transportasi publik ini yang menjadi leading sector adalah Dinas Perhubungan melalui BLU UPTD Trans Semarang.

\section{B. Pembahasan}

\section{Face to Face (Dialog Tatap Muka)}

Semua tata kelola kolaboratif dibangun berdasarkan dialog tatap muka antara para stakeholder, dialog tatap muka lebih dari sekedar media negosiasi namun ini adalah inti dari proses meruntuhkan stereotip dan hambatan komunikasi lainnya yang mencegah eksplorasi saling menguntungkan. Dialog tatap muka adalah jantung dari proses membangun kepercayaan, saling menghormati, saling pengertian dan komitmen untuk proses (Plummer, Ryan, 2004). Dialog tatatp muka adalah syarat yang diperlukan tapi tidak cukup untuk kolaborasi dibutuhkan 4 proses lainnya agar kolaborasi berjalan dengan baik. BLU UPTD Trans Semarang selaku leading sector telah melaksanakan dialog face to face dengan masingmasing stakholder secara rutin. Media komunikasi yang digunakan untuk berkomunikasi antar stakeholder adalah rapat koordinasi dan pertemuan informal. BAPPEDA lebih sering melakukan komunikasi dengan cara informal melalui pertemuan di restoran atau cafe agar suasana rapat lebih santai dan mengurangi ketegangan antar stakeholder jika terjadi perbedaan pendapat.

Selain pertemuan antar stakeholder, BLU UPTD Trans Semarang juga rutin mengadakan pengarahan kepada karyawannya dan pengemudi yang merupakan karyawan dari operator bus Trans Semarang. Pengarahan dilakukan untuk menyelaraskan visi dan misi dalam pelayanan transportasi publik ini.

Komunikasi yang sering dilakukan oleh BLU UPTD Trans Semarang ini menunjukkan bahwa kolaborasi dalam proses face to face ini berjalan dengan baik. Dengan komunikasi yang baik akan terjalin kesepahaman dalam melaksanakan kolaborasi untuk mencapai tujuan bersama.

Pertemuan rutin yang dilakukan oleh pihak-pihak dalam stake holder seharusnya membuat segala permasalahan bisa diselesaikan dengan cepat dan baik serta tidak terulang di masa yang akan datang. Proses kolaborasi pada tahap face to face ini berjalan dengan baik terbukti dengan seringnya 
dilakukan pertemuan baik secara formal maupun secara informal yang selanjutnya akan memberikan dampak kepada kualitas kolaborasi yang sejalan antara misi dan visi antar stakeholder.

\section{Trust Building (Membangun Kepercayaan)}

Kurangnya kepercayaan diantara stakholder adalah titik awal yang umum untuk tatat kelola kolaborasi (Weech-Maldonado \& Merrill, 2000). Proses kolaborasi tak hanya tentang negosiasi tetapi juga tentang membangun kepercayaan diantara stakeholder, meski sudah ada konlik masa lalu diantara para stakeholder, penulis menemukan bahwa membangun kepercayaan sering menjadi yang paling menonjol dalam aspek proses kolaborasi awal dan bisa sangat sulit untuk ditumbuhkan (Murdock, Wiessner, \& Sexton, 2005). Hal ini bukan untuk mengatakan bahwa membangun kepercayaan adalah fase terpisah dari dialog tatap muka dan negosiasi tentang masalah-masalah substantif, tapi pemimpin kolaboratif yang baik harus membangun kepercayaan diantara para penentang. Jika konflik masa lalu sangat antagonis, maka para stakeholder harus menganggarkan waktu untuk membangun kepercayaan yang efektif agar tidak mengganggu jalannya kolaborasi.

Pengaruh konflik masa lalu dalam membangun kepercayaan diakui oleh kepala BLU UPTD Trans Semarang msh ada. Seperti yang beliau sampaikan sebagai berikut :

"Ada beberapa orang yang berharap agar system digitalisasi yang kami dan teman-teman (BLU UPTD Trans) bangun tidak diberlakukan, sudahlah kembali ke system yang seperti biasa dengan pencatatan manual dan lain sebagainya."

Tahun ini BLU UPTD Trans Semarang melakukan perubahan dalam pelayanan yaitu digitalisasi pelayanan. Perubahan pelayanan menjadi digital ini bagi sebagian orang sangat menyulitkan. Hal inilah yang membuat beberapa orang ingin agar pelayanan tetap berjalan dengan cara tradisional atau sesuai dengan kebiasaan yang lalu. Pertentangan dari sebagian orang ini mungkin yang membuat pelayanan Trans Semarang terganggu dengan munculnya keluhan-keluhan pelayanan trans Semarang terkait pelaksanaan pelayanan digital. Hasil pengamatan peneliti menyatakan bahwa pelayanan petugas tiketing mendapat keluhan tertinggi dibidang pelayanan yang dilakukan oleh BLU UPTD Trans Semarang yaitu 93 keluhan selama tahun 2018. Petugas tiketing merupakan ujung tombak pelayanan Trans Semarang kepada pengguna jasa. Pelayanan petugas tiketing sudah menggunakan pembayaran elektronik atau digitalisasi pembayaran sehingga dengan adanya sebagian orang yang tidak mau beralih ke digitalisasi pelayanan akan mempengaruhi pelayanan petugas tiketing tersebut.

Menurut goverment of Canada mengenai terhambatnya jalannya suatu kolaborasi dan juga partisipasi adalah karena disebabkan oleh banyak 
faktor, terutama faktor-faktor budaya, faktor-faktor institusi-institusi dan faktor-faktor politik.

Permasalahan di internal BLU UPTD Trans Semarang adalah masih ada pihak-pihak yang menolak untuk mengikuti kebijakan dari Kepala BLU UPTD Trans Semarang yang menerapkan sistem digitalisasi dimana pihakpihak tersebut tidak mau mengikuti perkembangan teknologi yang diterapkan karena kesulitan dalam penerapannya. Dalam proses ini ada faktor budaya yang menghambat kolaborasi.

Untuk terciptanya kolaborasi yang efektif mensyaratkan para pelayan publik untuk memiliki ketrampilan dan kesediaan untuk masuk ke kemitraan yang sukarela dan berorientasi pada hasil. Pada permasalahan ini terlihat bahwa internal BLU UPTD Trans Semarang masih ada pihak-pihak yang belum memilliki ketrampilan dan kesediaan untuk melaksanakan kebijakan pimpinan berupa penerapan sistem digitalisasi pada pelayanan transportasi publik. sebagian kecil pihak tersebut belum memahami sistem digitalisasi yang diterapkan dan belum mempunyai ketrampilan untuk melaksanakan sistem digitalisasi tersebut.

Dalam proses Trust Building (Membangun Kepercayaan) ini ada kendala dalam melaksanakan kolaborasi yaitu faktor budaya dan faktor politik.

Dari segi budaya, kolaborasi seringkali gagal karena partisipasi dari kelompok kepentingan atau stakeholder lainnya selama ini sering kali masih dipandang bukan hal utama dan tidak diperlukan, tidak penting dan didominasi oleh kelompok dominan/pihak pemerintah melalui pendekatan top down. Kolaborasi juga bisa gagal karena strategi pecah belah dengan cara mengakomodasi kepentingan kelompok-kelompok yang pro kebijakan pemerintah dan mengabaikan kelompok yang anti kebijakan pemerintah (Sudarmo, 2009)

Di internal BLU UPTD Trans Semarang masih terdapat kelompokkelompok yang masih anti kebijakan pemerintah. Kebijakan digitalisasi merupakan salah satu strategi dari pimpinan BLU UPTD Trans Semarang untuk mengurangi kebocoran pendapatan dan alam rangka transparansi informasi kepada publik. Pihak-pihak yang menolak melaksanakan sistem digitalisasi beranggapan bahwa sistem tersebut ribet dan bisa menghambat mereka untuk berbuat tidak baik dalam proses penarikan pendapatan. Sistem laporan yang transparan dan dengan proses digital tanpa uang cash ini memang tidak memberikan celah untuk berbuat curang bagi pencuri-pencuri pendapatan Trans Semarang sehingga pihak tersebut tidak dapat melakukan kecurangan lagi.

Terkait dengan faktor politik, kolaborasi bisa terhambat, jika para pemimpin dari kelompok-kelompok yang berkolaborasi kurang atau tidak inovatif dalam mencapai tujuan-tujuan politik yang cenderung kompleks 
dan berpeluang menimbulkan konflik satu sama lain. Melalui kolaborasi ini konflik tujuan yang sering terpresentasikan sebagai tujuan masing-masing kelompok kepentingan bisa diminimalisir. Namun yang terjadi di internal BLU UPTD Trans Semarang, pimpinan BLU UPTD Trans Semarang belum bisa menyatukan tujuan dari beberapa pihak, hal ini terbukti dari adanya pihak yang masih belum mau melaksanakan kebijakan yang ditetapkan oleh kepala BLU UPTD Trans Semarang.

\section{Commitment To Process (Komitmen Pada Proses)}

Komitmen pada proses yang dimaksud adalah Komitmen dari para stakeholder dalam melakukan kolaborasi menjadi salah satu faktor dalam keberhasilan proses kolaborasi. Meskipun demikian dalam melaksanakan komitmen ini terkadang penuh dengan dilema. Misalnya stakeholder harus mematuhi hasil musyawarah sebagai bentuk komitmen walaupun keputusan tersebut mengharuskan bergabung dengan stakeholder yang berbeda pandangan. Oleh sebab itu maka komitmen memerlukan kepercayaan agar tanggung jawab masing-masing stakeholder dapat dijalankan dengan baik. Dalam konteks ini, komitmen pada proses merupakan konsekuensi atas keterlibatan dari masing-masing anggota dalam pelayanan Trans Semarang. Musyawarah yang dilakukan dalam kolaborasi ini terjadi karena adanya masalah dalam pelayanan Trans Semarang dan adanya keluhan dari pengguna jasa terhadap pelayanan yang dirasa kurang baik. Berdasarkan wawancara terhadap stake holder yang terlibat diketahui bahwa masalah yang masuk diidentifikasi, digolongkan untuk mengetahui tupoksi masingmasing yang menangani kemudian diserahkan ke masing-masing tupoksi yang menangani.

Setiap pembahasan masalah yang terkait dengan beberapa stakeholder dilakukan dengan musyawarah atau rapat koordinasi antar stakeholder, hal ini dilakukan karena masing-masing stakeholder memiliki peran dan fungsi yang berbeda. Dengan rapat koordinasi maka diharapkan permasalahan yang ada bisa segera diselesaikan secara bersama-sama. Musyawarah dilakukan oleh BLU UPTD Trans Semarang untuk menyatukan visi dan misi setiap stakeholder agar sepaham untuk peningkatan pelayanan Trans Semarang.

Dalam setiap rapat koordinasi hasil rapat tersebut dipatuhi oleh setiap stakeholder. Dari hasil wawancara terhadap 5 orang narasumber, semua menyatakan bahwa hasil rapat koordinasi selalu dipatuhi dan dilaksanakan oleh setiap stakeholder. Semua perbedaan pendapat diselesaikan didalam rapat.

Commitment to process menurut Ansell and Gash adalah mutual recognition of interdependence, shared ownership of process, openess to exploring mutual gains. Mutual recognition of interdependence adalah pengakuan atas saling ketergantungan dalam hal ini adalah pengakuan 
ketergantungan dalam melaksanakan kolaborasi. dalam pelaksanaan pelayanan transportasi publik Trans Semarang ini masing-masing stakeholder saling bergantung satu sama lain. Sebagai leading sector BLU UPTD Trans Semarang bergantung kepada stakeolder lain dalam menjalankan kolaborasi. BLU UPTD Trans Semarang, membutuhkan BAPPEDA Kota Semarang untuk merencanakan pengembangan pelayanan Trans Semarang, BLU UPTD Trans Semarang juga tidak bisa menjalankan operasional bus Trans Semarang tanpa melibatkan pengusaha selaku operator bus dan pelayanan trans Semarang tidak dapat dilaksanakan secara maksimal tanpa peran dari Dinas Pekerjaan Umum yang membangun dan merawat prasarana jalan seperti Shelter dan jalan untuk operasional bus.

Shared ownership of process berarti saling berbagi dalam proses kolaborasi. Dalam berkolaborasi masing-masing stakeholder dituntut untuk saling terbuka satu sama lain, jujur dan saling berbagi. Saling berbagi dalam proses sangat diperlukan karena masing-masing stakeholder saling terlibat dalam proses kolaborasi pelayanan transportasi publik ini. Karena semua stakeholder terlibat maka semua harus mengetahui proses yang dilaksanakan oleh masing-masing stakeholder dengan cara saling berbagi antar stakeholder. Dengan saling berbagi proses identifikasi permasalahan menjadi lebih mudah dan cepat karena masing-masing stakeholder sudah berbagi proses sehingga BLU UPTD Trans Semarang sebagai leading sector lebih mudah mengidentifikasi masalah karena sudah memiliki data yang di shared oleh masing-masing stakeholder.

Openess to exploring mutual gains adalah keterbukaan untuk mengexplorasi keuntungan bersama. Dalam berkolaborasi ini tujuan utama adalah untuk melaksanakan pelayanan transportasi publik, namun disamping tujuan utama terdapat juga tujuan bagi masing-masing stakeholder. Bagi stakeholder dari pihak pemerintah tujuan dari melakukan kolaborasi ini adalah memberikan pelayanan transportasi bagi masyarakat, meningkatkan perekonomian masyarakat dengan cara membantu mobilitas masyarakat dan meningkatkan kesejahteraan masyarakat melalui bidang transportasi. Bagi operator tujuan dari kolaborasi ini adalah untuk mendapatkan keuntungan bagi mereka. Keuntungan yang diharapkan oleh operator adalah keuntungan dari segi ekonomi bagi operator, penyerapan tenaga kerja serta pengembangan usaha bagi operator.

Setiap stakeholder yang bergabung dalam kolaborasi sudah mengetahui tujuan utama dalam kolaborasi ini, yaitu untuk memberikan pelayanan transportasi bagi masyarakat semarang yang aman, nyaman dan murah. selain itu setiap stakeholder juga wajib mengetahui tujuan personal dari masing-masing stakeholder dalam menjalankan kolaborasi tersebut. Pencapain tujuan personal dari masing-masing stakeholder berguna untuk memotivasi masing-masing stakeholder untuk mencapai tujuan bersama. 
Dari hasil wawancara dengan operator yaitu PT. Minas dan PT. Matra Semar tujuan personal yang sudah dicapai oleh para operator ini yaitu

1) Omset dan aset perusahaan yang meningkat.

2) Perusahaan dapat membuka lapangan kerja

3) Pengusaha angkutan kota dapat beralih profesi menjadi operator bus Trans Semarang.

4) Kondisi armada bus Trans yang lebih baik

5) Sistem transportasi yang lebih tertib dan teratur

Bagi pemerintah dalam hal ini BLU UPTD Trans Semarang, BAPPEDA dan DPU kolaborasi ini telah mencapai apa yang menjadi tujuan personal pemerintah yaitu :

1) jangkauan pelayanan transportasi bertambah luas,

2) masyarakat lebih mudah dalam mendapatkan pelayanan transportasi.

3) jumlah prasarana seperti shelter dan juga inovasi dalam bidang teknologi juga bertambah,

4) jumlah penumpang meningkat sehingga pendapataan daerah juga ikut meningkat.

5) Sedangkan bagi Pemerintah Kota Toyama sebagai negara donor, hasil yang dicapai adalah menurunnya emisis gas buang dari 31,6 5 menjadi $17.85 \%$.

Dengan tercapainya tujuan utama dan tujuan personal dalam kolaborasi pelayanan transportasi publik ini yang berarti masing-masing stakeholder sudah saling berbagi dalam keterbukaan untuk mengexplorasi keuntungan bersama maka Openess to exploring mutual gains telah terlaksana dalam proses commitment to process (komitmen pada proses) ini.

\section{Share Understanding (Pemahaman Bersama)}

Share Understanding menurut Ansell and Gash adalah meliputi : clear mission, common problem definition dan identification of common value.

Clear mission yang berarti visi dan misi yang jelas. Pelayanan transportasi publik Trans Semarang ini telah memiliki visi dan misi yang jelas yaitu adalah sebagai berikut :

Visi dari kolaborasi pelayanan transportasi publik ini adalah Menciptakan Pelayanan BRT yang Profesional, Mandiri, Dapat Diandalkan, Berkesinambungan dan Terjangkau.

Common problem definition berarti mendifinisikan permasalahan yang sering terjadi didalam kolaborasi pelayanan transportasi publik ini. Masalah yang masuk diidentifikasi kemudian didefinisikan dan dikelompokkan sesuai dengan tanggung jawab masing-masing stakeholder. Common problem definition berkaitan erat dengan identification of common value yang berarti identifikasi nilai-nilai umum, proses ini berurutan. 
Permasalahan yang masuk didefinisikan kemudian diidentifikasi. Yang telah terjadi didalam kolaborasi pelayanan transportasi publik ini setiap keluhan pelanggan dan permasalahan yang terjadi dalam pelayanan Trans Semarang semuanya masuk ke BLU UPTD Trans Semarang. Oleh BLU UPTD Trans Semarang semua permasalahan tersebut diidentifikasi dan didefinisikan untuk diketahui stakeholder mana yang akan menyelesaikannya.

Dalam kolaborasi penyelenggaraan transportasi publik ini, masingmasing Stakeholder sudah sepaham dalam menjalankan peran masingmasing. Hal ini sudah penulis sampaikan di Analisis data penelitian, namun masih ada ketidaksesuaian antara keinginan pengusaha selaku operator dan BLU UPTD Trans Semarang selaku leading sector yang mengatur anggaran dalam pelayanan transportasi publik ini.

\section{Intermediate Out Comes (dampak sementara)}

Dalam proses kolaborasi dalam pelayanan transportasi publik ini, selain tujuan untuk memberikan pelayanan kepada masyarakat tentunya masing-masing aktor memiliki tujuan masing-masing untuk mendapatkan manfaat dari kolaborasi tersebut. Intermediate out comes bisa diartikan juga sebagai.

Intermediate out comes menurut Ansell and Gash adalah small wins, strategic plan and joint fact finding. Small wins yang berarti kemenangan kecil sebelum mencapai kemenangan besar. Kemenangan kecil ini adalah tujuan antara sebelum mencapai tujuan akhir dalam kolaborasi pelayanan transportasi publik ini. Jika tujuan utama dari kolaborasi adalah untuk memberikan pelayanan transportasi publik bagi masyarakat, maka tujuan antara adalah manfaat bagi masing-masing stakeholder.

Small wins bagi pemerintah dalam hal ini Dinas Perhubungan melalui BLU UPTD Trans Semarang, BAPPEDA dan Dinas Pekerjaan Umum adalah :

1) Meningkatnya pelayanan kepada masyarakat dalam bidang transportasi umum, jumlah koridor yang bertambah berarti menambah luas cakupan layanan Trans Semarang,

2) Meningkatnya kesejahteraan bagi karyawan BLU UPTD Trans Semarang,

3) Bertambahnya lapangan pekerjaan dalam sektor transportasi dimana BLU UPTD Trans Semarang tiap tahun membutuhkan sekitar 200 orang karyawan,

4) Bertambah jumlah dan kualitas sarana prasarana dalam bidang transportasi publik ini seperti halte bertambah banyak dan bertambah indah, pedestrian atau trotoar sekitar halte Trans Semarang ikut menjadi lebih indah,

5) Kemacetan lalu lintas ikut berkurang dengan banyaknya pengguna bus Trans Semarang, 
6) Subsidi pada tarif pelajar membuat jumlah penumpang dari pelajar meningkat, sehingga permasalahan lalu lintas yang diakibatkan oleh pemakaian sepeda motor oleh pelajar ikut berkurang.

7) Program Bahan Bakar Gas yang diterapkan oleh pemerintah Kota Semarang juga ikut mnyumbang turunnya emisi gas buang yang disebabkan oleh bus-bus Trans Semarang.

Sedangkan Bagi operator bus Trans Semarang, small wins yang telah dicapai adalah:

1) Keuntungan financial bagi perusahaan.

2) Perusahaan dapat membuka lapangan kerja

3) Pengusaha angkutan kota dapat beralih profesi menjadi operator bus Trans Semarang.

4) Kondisi armada bus Trans juga lebih baik

Dengan banyaknya small wins yang telah dicapai menunjukkan bahwa kolaborasi pada proses Intermediate Out Comes telah tercapai.

Strategic plan adalah perencanaan strategis yang akan dilakukan untuk meningkatkan kualitas kolaborasi dengan cara memperbaiki layanan dengan melakukan inovasi pada pelayanan.

Masing-masing stakeholder dalam pelayanan transportasi publik ini sudah berinisiatif untuk melakukan inovasi untuk meningkatkan pelayanan transportasi publik ini.

Pihak BLU UPTD Trans Semarang dan Bapppeda selaku pemerintah telah melakukan inovasi berupa :

1) BBG bagi bahan bakar bus yang bertujuan untuk menekan emisi gas buang agar lebih ramah lingkungan,

2) Program Customer Care yang membuat petugas dilapangan lebih ramah dan lebih perduli terhadap penumpang.

3) Halte-halte dibuat lebih bagus agar penumpang lebih nyaman dalam menunggu kedatangan armada Trans Semarang.

4) Passenger Information System yaitu sistem informasi bagi penumpang untuk mengetahui posisi bus dan waktu tunggu bus.

5) Dedicated line yaitu sistem Bus Way atau lajur khusus bus Trans Semarang yang bertujuan agar perjalanan bus tidak bercampur dan terganggu dengan lalu lintas lain.

Pihak operator bus juga tidak kalah dalam berinovasi, beberapa inovasi telah diterapkan dan beberapa telah disiapkan untuk meningkatkan pelayanan Trans Semarang. Inovasi yang telah diterapkan oleh operator busa adalah :

1) Melaksanakan pelatihan bagi karyawan, yang bertujuan untuk meningkatkan kapasitas SDM dari karyawan,

2) Uji kelayakan karyawan, 
3) Pemasangan GPS di armada bus agar kecepatan dan posisi bus bisa dipantau.

Joint fact finding adalah sebuah proses untuk mengenali dan mendefinisikan masalah yang dihadapi oleh organisasi sebagai dasar acuan untuk penyusunan langkah selanjutnya bagi stakeholder dan sebagai masukan kebijakan bagi pihak manajemen. Hal lazim yang dilakukan dalam tahap joint fact finding adalah kegiatan research. Joint Fact Finding ini menjadi tugas dari BLU UPTD Trans Semarang selaku leading sector dan BAPPEDA selaku stakeholders yang mempunyai tupoksi perencanaan. Stakeholders dari pihak pemerintah sudah mengidentifikasi masalahmasalah yang dihadapi dalam pelayanan transportasi publik ini serta telah menyusun rencana-rencana strategis untuk meningkatkan pelayanan Trans Semarang. Banyak rencana strategis sudah dikaji dan disiapkan oleh pemerintah antara lain :

1) Dedicated line, jalur khusus bus agar tidak bercampur dengan lalulintas angkutan lain sehingga waktu tempuh lebih cepat dan rute perjalanan bus lebih aman.

2) Program bahan bakar gas pada seluruh armada bus Trans Semarang.

3) Full digitalisasi system pada semua aspek pelayanan Trans Semarang mulai dari pembayaran, informasi penumpang hingga pelaporan pelayanan trans Semarang.

4) Uji coba bus tipe low deck, selama ini semua bus trans Semarang bertipe high deck yaitu bus yang memiliki tinggi lantai $50 \mathrm{~cm}$ dari atas tanah, sehingga bus hanya bisa menaikkan dan menurunkan penumpang di halte khusus Trans Semarang. Pada tahun 2019 ini Dinas Perhubungan Kota Semarang mendapat bantuan 2 unit bus tipe low deck dari Kementerian Perhubungan Republik Indonesia dan sudah mulai diuji coba pada bulan November 2019. Tujuan uji coba bus low deck ini adalah untuk menguji konektifitas antara Trans Semarang dengan angkutan umum lain yang bertipe low deck.

Pencapaian hasil sementara pada small wins, strategic plan and joint fact finding seperti yang telah penulis uraikan diatas menunjukkan bahwa kolaborasi pada proses Intermediate Out Comes berjalan dengan baik.

\section{Kesimpulan}

Berdasarkan hasil dari penelitian disimpulkan bahwa :

1. Proses Kolaborasi dalam pelayanan Transportasi publik

a. Face To Face (Dialog Tatap Muka)

- Komunikasi terjalin dengan baik, rapat koordinasi antar stakeholder membahas evaluasi dan rencana dalam pelayanan transportasi Trans Semarang diselenggarakan secara rutin. 
- Komunikasi kepada karyawan yang melakukan pelayanan juga terjalin dengan baik, pengarahan-pengarahan terhadap karyawan dan pengemudi yang diadakan minimal 1 kali dalam sebulan.

b. Trust Building (Membangun Kepercayaan)

- Terjadi konflik masa lalu antar stakeholder, namun konflik bisa diselesaikan dengan mengadakan sosialisasi dan pendekatan persuasif ke masing-masing stakeholder.

- Konflik yang terjadi antar stakeholder ini tidak mempengaruhi proses kolaborasi karena telah berhasil diselesaikan.

- Selain konflik antar stakeholder, terjadi konflik internal BLU UPTD Trans Semarang. Konflik terjadi karena sebagian pihak menolak melaksanakan kebijakan pimpinan. Konflik menghambat proses kolaborasi karena pertentangan dari sebagian orang ini membuat pelayanan Trans Semarang terganggu dengan munculnya keluhan-keluhan pelayanan trans Semarang terkait pelaksanaan pelayanan digital khususnya tiketing. Proses membangun kepercayaan di internal UPTD Trans Semarang belum berhasil.

c. Comitment To Prosses (Komitmen Pada Proses)

- Sudah ada prosedur dalam penanganan masalah.

- Penyelesaian masalah melalui musyawarah atau rapat koordinasi antar stakeholder.

- Hasil musyawarah atau rapat koordinasi dipatuhi secara bersama-sama. Dalam proses ini, kolaborasi berjalan dengan baik.

d. Share Understanding (Pemahaman Bersama)

- Terjadi ketidaksesuaian antara keinginan operator terhadap pembayaran biaya operasional kendaraan dengan besaran biaya operasional kendaraan yang dibayarkan oleh BLU UPTD Trans Semarang,

- Keinginan operator untuk menambah operasional kendaraan melebihi ketentuan di perjanjian kontrak untuk menutupi jarak (kilometer) tempuh yang tidak tercapai karena kendala lalu lintas.

- Operator melakukan efisiensi terhadap operasional busnya dengan cara : menambah jam kerja pengemudi melebihi ketentuan perundang-undangan dan memperlambat pergantian spare part kendaraan. Efisiensi yang dilakukan oleh operator ini lah yang membuat pelayanan Trans Semarang menurun sehingga menimbulkan keluhan dari pengguna jasa.

\section{e. Intermediate Outcomes (Dampak Sementara)}

Adapun dampak sementara yang telah dihasilkan dari kolaborasi ini adalah :

- Pelayanan Trans Semarang semakin bertambah luas dan bertambah banyak sehingga lebih luas menjangkau kepada masyarakat, 
- Meningkatnya jumlah penumpang yang berarti mengurangi jumlah kendaraan yang beroperasi di jalan sehingga ikut mengurangi tingkat kemacetan dan tingkat kecelakaan di jalan,

- Membantu mengurangi pencemaran lingkungan dengan penggunaan bahan bakar gas,

- Memberikan peluang usaha bagi pengusaha angkutan kota untuk beralih profesi sebagai operator bus Trans Semarang,

- Membuka lapangan kerja bagi masyarakat untuk bergabung sebagai karyawan Trans Semarang maupun karyawan perusahaan operator.

2. Faktor penghambat dalam pelayanan transportasi publik

a. Budaya

- Budaya "top down" oleh pemerintah menjadi faktor penghambat dalam proses kolaborasi pelayanan transportasi publik ini, semua kebijakan berasal dari pihak pemerintah, operator hanya sebagai pelaksana.

- Dalam tahap Share Understanding penetapan besaran biaya operasional kendaraan yang ditetapkan oleh BLU UPTD Trans Semarang tidak sesuai dengan yang diharapkan oleh operator.

b. Institusi

- Kecenderungan stakeholder yang terlibat dalam kolaborasi cenderung menerapkan struktur hirarkis terhadap stakeholder lain yang ikut terlibat dalam kolaborasi pelayanan transportasi publik ini telah membuat kolaborasi terhambat.

- Penerapan kebijakan yang hirarkhis tentang penerapan sistem digitalisasi dan penerapan harga Biaya operasional kendaraan yang sepihak oleh BLU UPTD Trans Semarang telah menghambat proses kolaborasi. 


\section{BIBLIOGRAFI}

Mardalis. (n.d.). Metode Penelitian Suatu Pendekatan Proposal. Jakarta: Bumi Aksara.

Moleong, Lexy. (2005). Metode Penelitian Kualitatif, edisi revisi, Penerbit: PT. Remaja Rosdakarya, Bandung.

Murdock, Barbara Scott, Wiessner, Carol, \& Sexton, Ken. (2005). Stakeholder participation in voluntary environmental agreements: Analysis of 10 Project XL case studies. Science, Technology, \& Human Values, 30(2), 223-250.

Plummer, Ryan, and John Fitzgibbon. (2004). Co-management of natural resources: A proposed framework (33rd ed.). Environmental Management.

Sudarmo. (2009). Elemen-Elemen Collaborative Leadership dan Hambatan-Hambatan Bagi Pencapaian Efektivitas Collaborative Governance. ., No.2,ISSN 1907-0489. Jurnal Spirit Publik, Vol.5, 117-132.

Sugiyono, Metode Penelitian. (2016). Pengembangan Research and Development. Bandung: Alvabeta.

Suhaeri, Suhaeri. (2018). Strategi Komunikasi Inovasi Dalam Meminimalisir Konflik Horizontal Pengemudi Taksi Online Dan Konvensional Di Kota Bandung. Syntax Literate; Jurnal Ilmiah Indonesia, 3(2), 122-131.

Weech-Maldonado, Robert, \& Merrill, Sonya B. (2000). Building partnerships with the community: lessons from the Camden Health Improvement Learning Collaborative. Journal of Healthcare Management, 45(3), 189-205. 